\title{
松原ダム湖の風と波 WIND AND WAVE IN THE MATSUBARA DAM LAKE
}

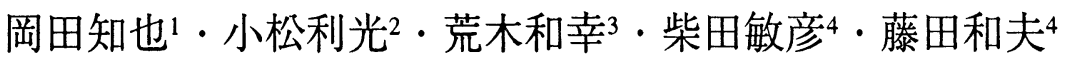 \\ Tomonari OKADA, Toshimitsu KOMATSU, Kazuyuki ARAKI, \\ Toshihiko SHIBATA and Kazuo FUJITA
}

\begin{abstract}
1学生員 工修 九州大学大学院 工学研究科博士後期課程 日本学術振興会特別研究員
（下812-81 福岡市東区箱崎 $6-10-1$ )

2 フェロー 工博 九州大学教授 工学部建設都市工学科 (同上)

3正会員 建設省九州地方建設局 九州技術事務所 （T830 久留米市高野町 3435-5）

${ }^{4}$ 正会員 九州大学技官 工学部建設都市工学科 （テ812-81 福岡市東区箱崎 6-10-1）
\end{abstract}

\begin{abstract}
Observations of winds and waves were carried out at the Matsubara dam lake for two months from December in 1996. An observation point was set up at the center of the lake and was three hundred meters far from the land. After making an analysis of observed data, we obtained the following results. (1) the heights of wind waves were generally $6 \mathrm{~cm}$ or less. (2) the range of wave period was from $0.4 \mathrm{~s} \mathrm{to} 1.0 \mathrm{~s}$. (3) most of observed waves were not the steady state but duration-limited waves. (4) it is possible to estimate wind waves in the Matsubara dam lake by using the fetch relation if we use a representative fetch that depends on the water area.
\end{abstract}

Key Words: Matsubara dam lake, reservoir, wind wave, wave observation

\section{1.はじめに}

ダム湖や貯水池のような比較的狭い水域に発生す る波浪は海洋に発生する波浪と比較すると格段に小 さく弱いことから，その特性を知ることはこれまで のところ工学上, 特に防災上それ程重要ではなくあ まり顧みられなかった。しかしながら近年, ダム湖 や貯水池に発生する波のエネルギーを利用した水質 改善法が提案1),2)される等, 徐々に研究者に見直され るようになってきており比較的狭い領域に発生する 波の特性を知ることは環境問題上重要になってい る.

比較的狭い水域に発生する波の観測としては，高

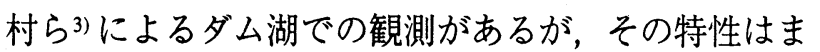
だほとんど明らかにされていない，一方，ダム湖や 眝水池と較べるとかなり大きな水域であるが, 琵琶

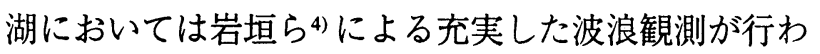
れており，周期については Wilson IV 型に良く一致 し，また波高についてはばらつきが大きく
Bretschneider の修正曲線と Wilson IV 型のどちらに 合うのか判然としないと報告されている。

著者らは, 筑後川上流に位置する松原ダムのダム 湖において波浪観測の機会を得ることができた。そ こで 1996 年 12 月 28 日〜 1997 年 2 月 23 日までの 2 ケ月間にわたり波浪観測を実施したので，その結果 を報告する。

本報告の目的は，松原ダム湖に発生する波浪の大 きさを知ること，および松原ダム湖に発生する波浪 の推算を可能にすることである.ダム湖は一般に複 雑な地形で囲まれている水域であるため，一面に開 けた海洋のような水域とは異なり, 風速および吹送 距離がかなり複雑に变化する。このような場では波 と風の関係は吹送距離則に単純には一致しない。そ こで水域の空間スケールを代表的な吹送距離とする 概念を用いて，波と風を関係付ける試みを行った。

また，複雑な地形に囲まれた狭い水域に発生する 波浪場は周囲の地形からの反射や散乱の影響を受け る場合が多く，そのような波浪場の波の特性を知る 


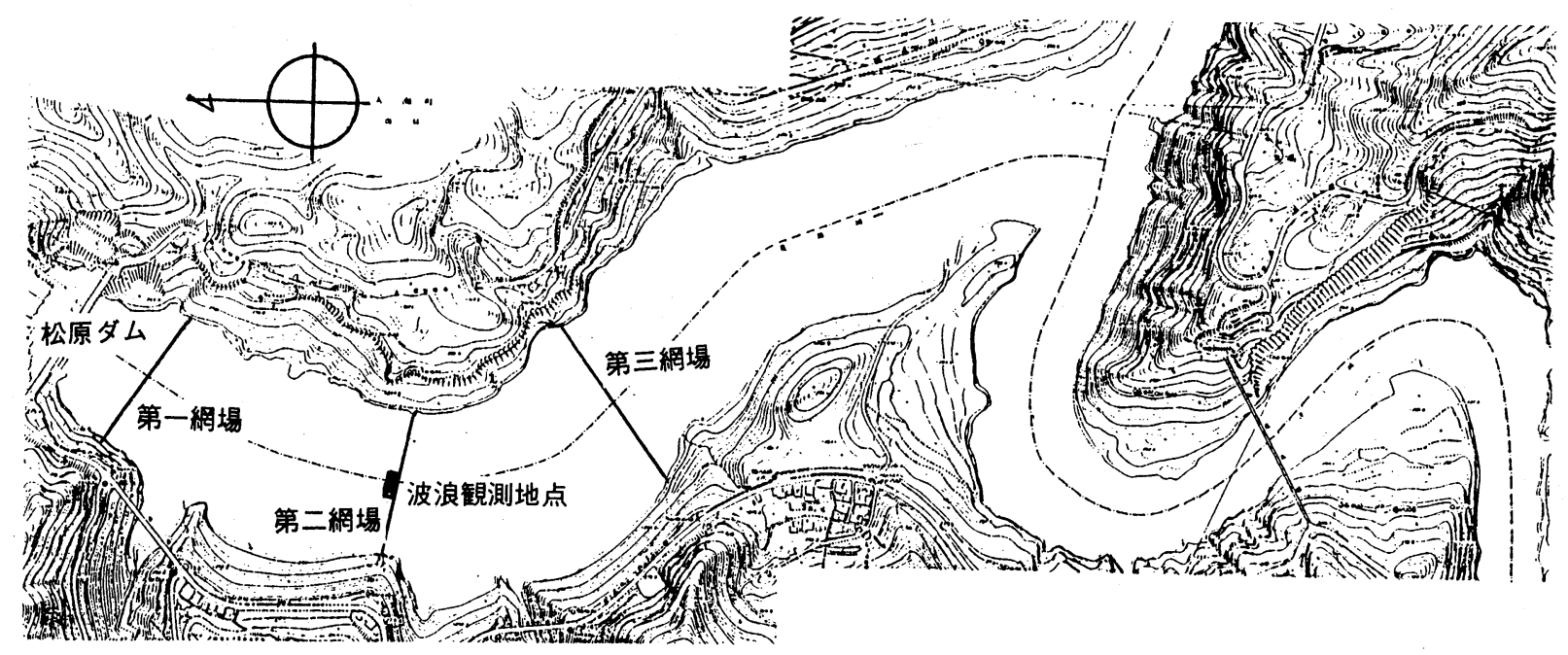

図一１松原ダム湖の形状と波浪観測地点

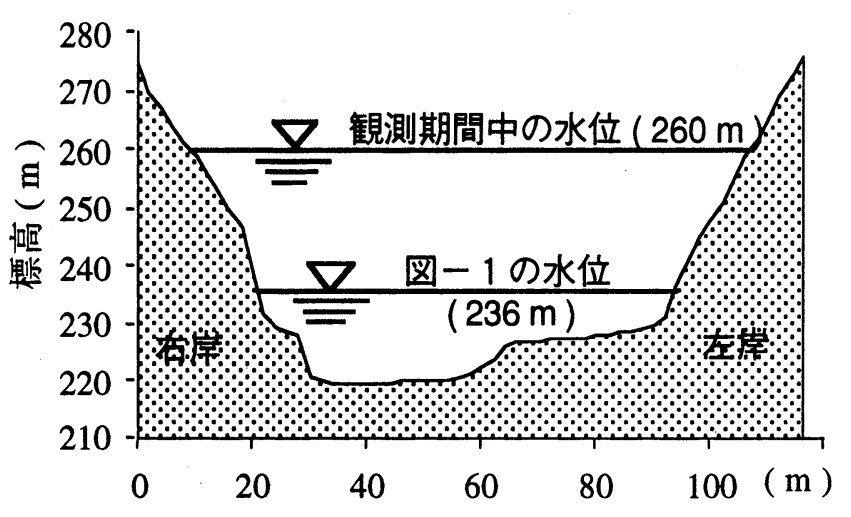

図ー2 ダム湖の横断面図（観測地点付近）

ためには方向スペクトル解析は不可欠である，松原 ダム湖はまさに複雑な地形に囲まれた狭い水域で あったが, 波高が数 $\mathrm{cm}$, 波長が高々 $1 \mathrm{~m}$ 程度と非 常に小さいためか, ダム湖中央の観測地点において は少なくとも反射波や散乱波の影響は観察されな かった．したがって，本報告では周囲の地形からの 反射波等の影響は無視できるものと敒定して検討を 行った.

\section{2. 観測装置及び観測方法}

\section{（1）ダム湖の地形と波浪観測地点}

松原ダム湖は両側を山に挟まれていて南北（流下 方向）に長く，「く」の字型の形状をした水域であ る（図一 1 参照）。図ー 1 は水位が $236 \mathrm{~m}$ の場合を 示している。観測期間中の水位は $260 \mathrm{~m}$ であった。 等高線の太線は $10 \mathrm{~m}$ 間隔を示しており，観測期間中 の実際の水面形は図中の等高線の下から 3 本目の太

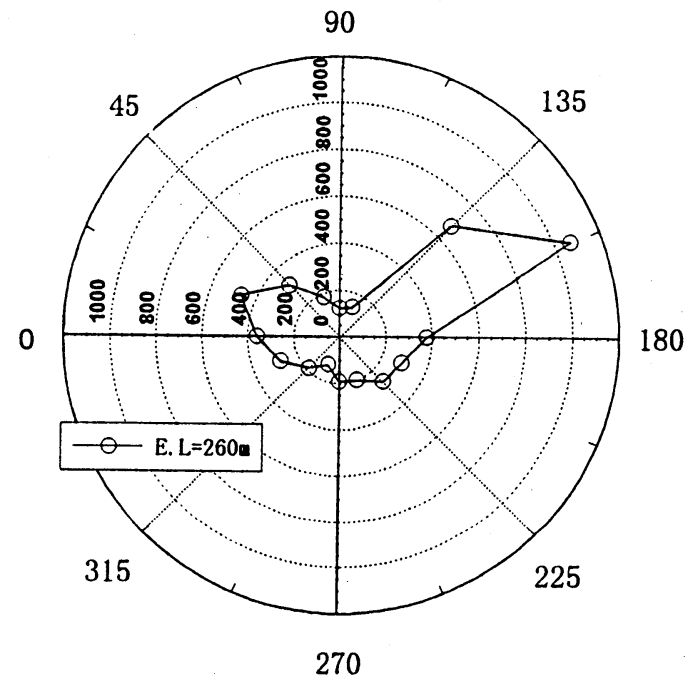

図一３観測地点から陸岸までの距離

線に一致する. 図一 2 は観測地点付近のダム湖の横 断面図を示したものである。湖底の標高は $220 \mathrm{~m} て ゙$ あることから，観測期間中の湖中央部の水深は $40 \mathrm{~m}$ であったことになる。 また，図一 1 および図一2 ら岸付近の湖底の勾配は殆ど全ての領域で $45^{\circ}$ 以上 であり，ダム湖に発生する波長が高々 $1 \mathrm{~m}$ 程度の波 に対しては, 松原ダム湖はほほ全域が深水域と言え る.

ダムサイトからおよそ 100, 300, $600 \mathrm{~m}$ のところ には流木防止ネット（網場）が施されており，ダム から $300 \mathrm{~m}$ のところの第二網場に設置されている作 業台上で観測を行った。作業台はフロートを用いて 浮設されているため水位の変動には追随するが, 風 や波により振動を生じるという問題がある. 観測地 点から陸岸までの距離を図ー3に示す，方位を 16 分割して観測期間中の水位 $260 \mathrm{~m}$ の場合に対して地 図から読み取ったものである。図中 $0,90,180,270$ は それぞれ北, 東, 南, 西に対応している. 今回の観 


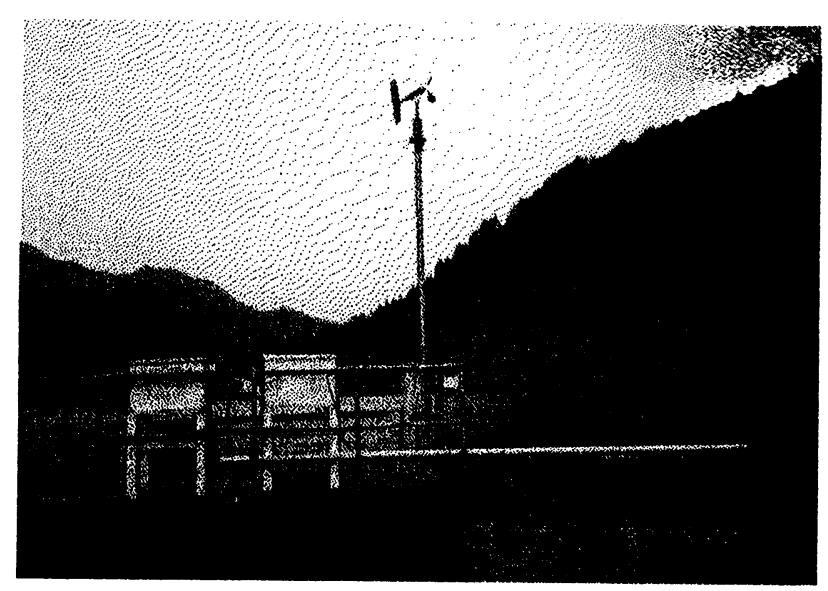

写真一 1 波浪観測システム

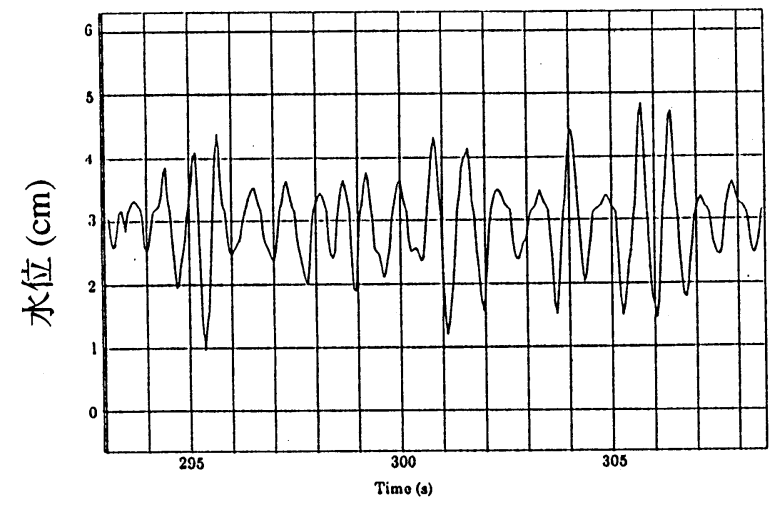

図－5 波高記録の一部を拡大したもの

測地点から陸岸までの最大距離は南南東に $1067 \mathrm{~m}$, 最小距離は東に $125 \mathrm{~m}$ であった。

\section{（2）波浪測定システム}

波浪測定には長さ $30 \mathrm{~cm}$ の容量式波高計（横河 ウェザック社製の CW2-003-H型）一台を用い, サン プリング間隔 $0.01 \mathrm{~s}$, 測定時間 10 分間、測定間隔 2 時間でデータを採取した。作業台からの反射波をな るべく避けるため, 作業台から $2 \mathrm{~m}$ 張り出したパイ プに波高計は設置されている（写真－1参照）。

風向と風速は微風向風速発信器 $(0.4 \sim 20 \mathrm{~m} / \mathrm{s})$

（横河ウェザック社製の A-733 型）を用いて測定し た。波浪データと同様にサンプリング間隔 $0.01 \mathrm{~s}$ ， 測定時間 10 分間, 測定間隔 2 時間で, 波浪デー夕と 同時刻の風向・風速のデータを採取している，標準 的な風速の值である $U_{10}$ を得るため, 本来, 水表面 上 $10 \mathrm{~m}$ 地点もしくは鉛直方向に複数点で風の観測が なされるべきであるが, 設置の安定性の問題から本 観測は水表面上 $4.0 \mathrm{~m}$ 地点のみで行われた（写真一 1 参照）。

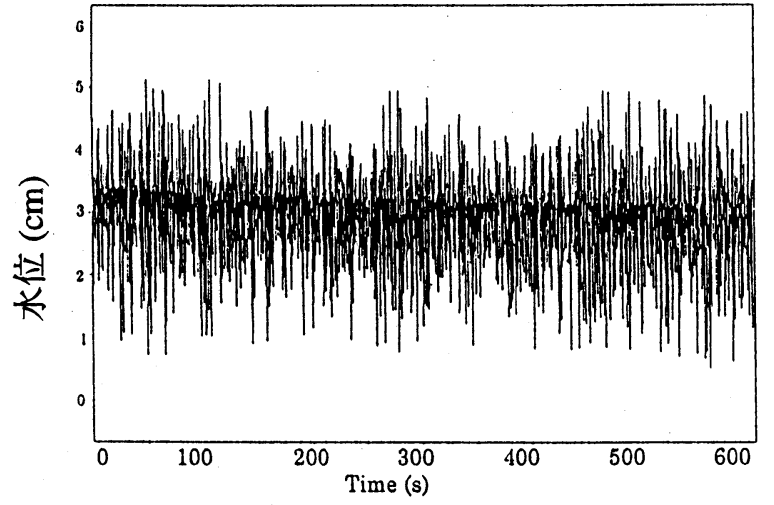

図-4 波高記録の一例

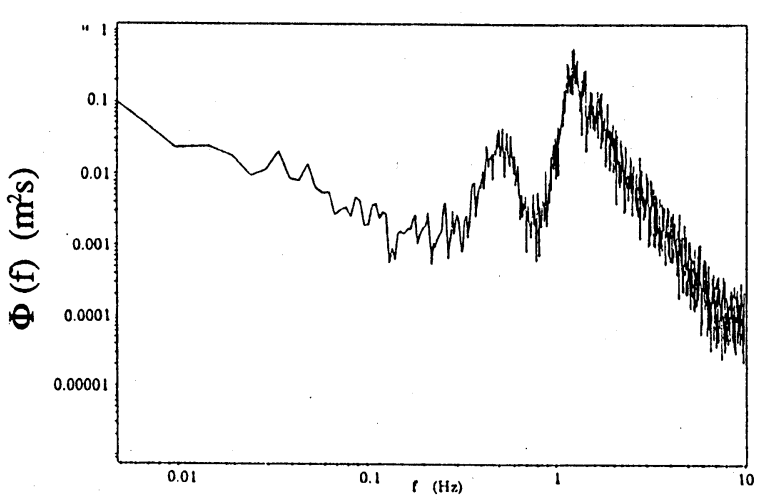

図ー6 周波数スペクトルの一例

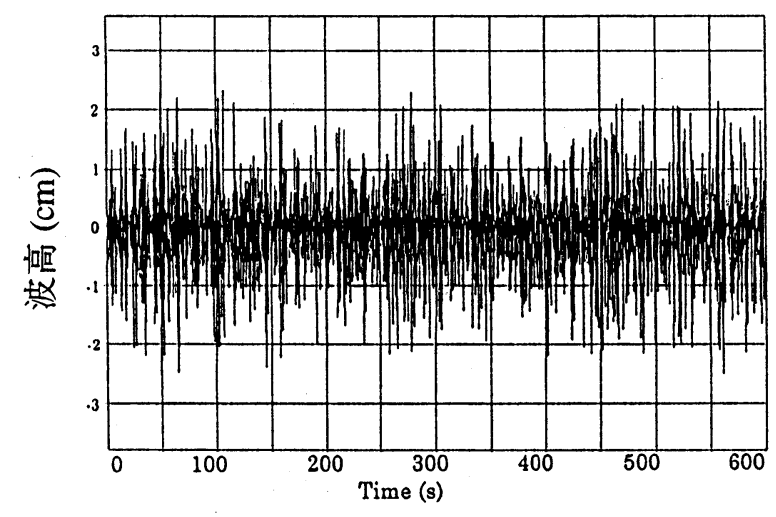

図ー7 作業台の振動成分が除去された波高データ

\section{3. 諸量の決定}

\section{（1）有義波高}

図一 4 は波高記録の一例であり, 図一 5 は図一 4 の一部を拡大したものである。図一 6 は図一 4 に対する周波数スペクトルである. 図一 6 から卓越 周波数は $\mathrm{f}=0.4 \mathrm{~s}^{-1}$ と $1.5 \mathrm{~s}^{-1}$ の 2 つあることが分か る.このような双子山の傾向は他の多くのデー夕に 対しても見られた。周波数 $0.4 \mathrm{~s}^{-1}$ と $1.5 \mathrm{~s}^{-1}$ を周期で 表わすと $2.5 \mathrm{~s}$ と $0.67 \mathrm{~s}$ である. 図一 5 から風波の 波動成分の周期は概ね $1 \mathrm{~s}$ 以下であり, 周期 $2.5 \mathrm{~s}$ 前 後の波動成分は作業台の振動および網場のフロート 


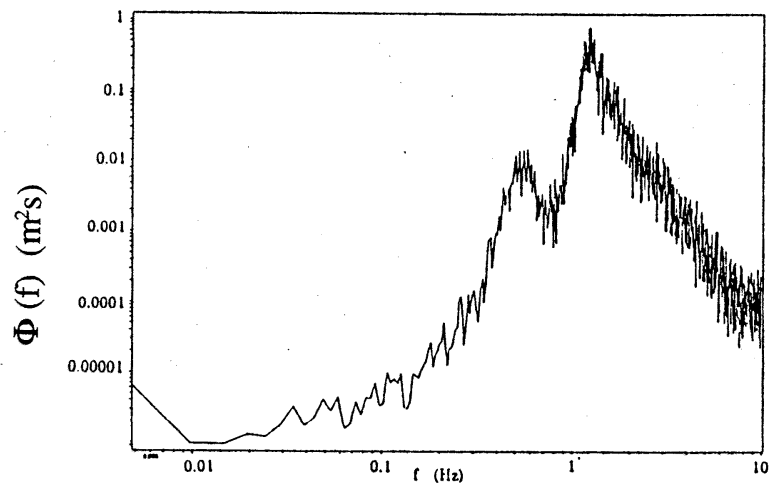

図ー8 作業台の振動成分が除去された波高デー夕の周 波数スペクトル

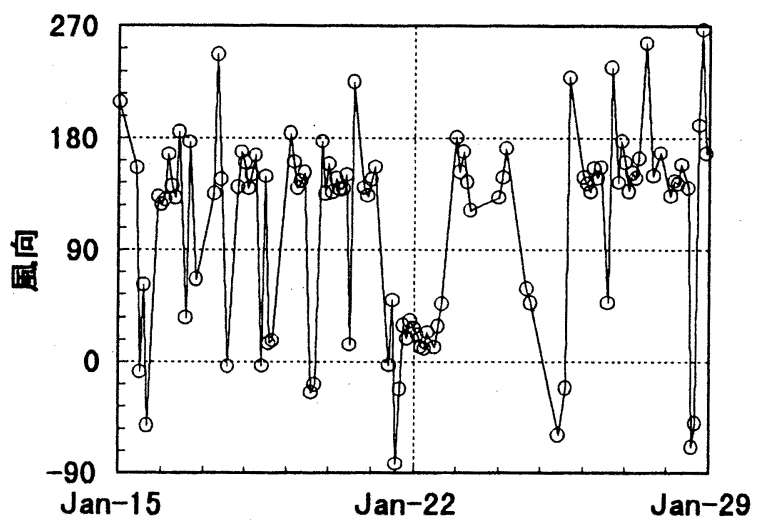

図-10 風向の経時変化の一例

の振動によって生じた波動成分と考えられる。そこ で，作業台の変動成分および網場のフロートの振動 によって生じた波動成分の除去を行うことにした。

図一 6 から双子山の谷の周波数はおおよそ $\mathrm{f}=0.8$ $\mathrm{s}^{-1}$ である。图ー7は観測データから $1.25 \mathrm{~s}$ 間の単純 移動平均を施されたデー夕を差し引いたものであ る。図ー8は図一 7 に対する周波数スペクトルであ る. $\mathrm{f}=0.4 \mathrm{~s}^{-1}$ 前後の雑音は完全に除去するまでには 至らなかったが, 今回はこのデー夕を用いて有義波 高 $\mathrm{H}_{1 / 3}$ および有義周期 $\mathrm{T}_{1 / 3}$ の算出を行った。

\section{（2） $U_{10}$ の決定について}

観測された 10 分間の風速デー夕を平均すること によって風速 $\mathrm{U}_{4}$ とした．前述したように今回の風の 観測は水面上 $4 \mathrm{~m}$ 地点で行われたため, 得られた風 速 $U_{4}$ から次のような過程で $U_{10}$ を決定した. 風速 分布を次式

$$
\begin{gathered}
\mathrm{U}_{\mathrm{z}}=\frac{2.303}{\kappa} \mathrm{U}_{*} \log \frac{\mathrm{z}}{\mathrm{z}_{0}} \\
\mathrm{\kappa}: \text { Karman の定数 }(\fallingdotseq 0.4), \\
\mathrm{U}_{*}: \text { 摩擦速度, } \\
\mathrm{z}_{0} \quad \text { : 水面の粗度定数 }
\end{gathered}
$$

に従うものとし5)，また， $\mathrm{U}_{*}$ はいかなる $\mathrm{U}_{10}$ に対し

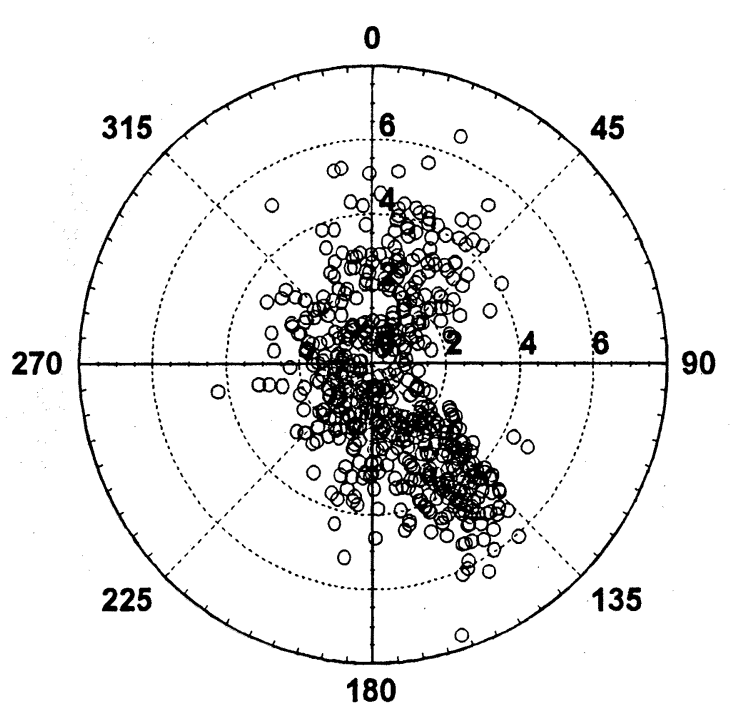

図一－風速と風向の関係

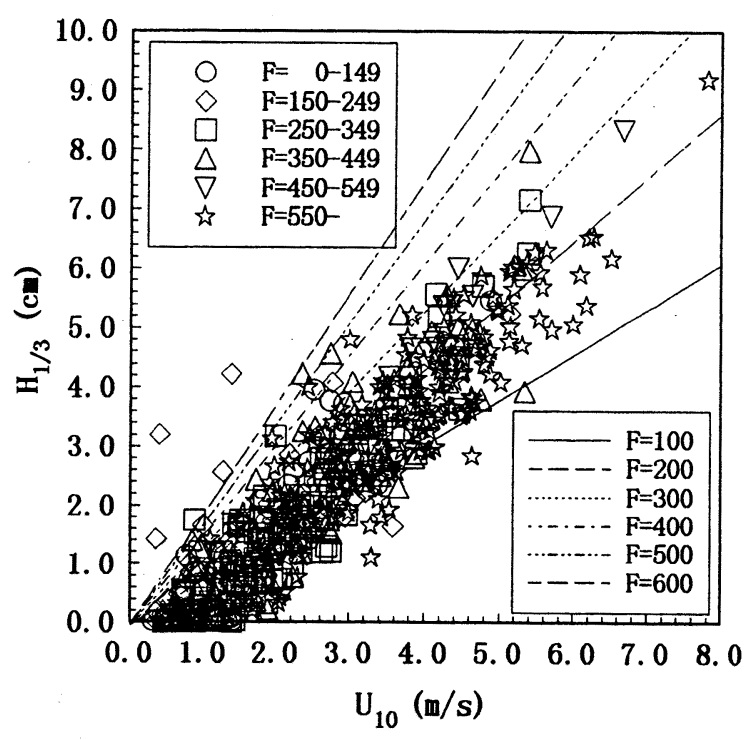

図ー11 $\mathrm{H}_{1 / 3}$ と $\mathrm{U}_{10}$ の関係

ても

$$
\mathrm{U}^{2}{ }^{2}=\mathrm{C}_{\mathrm{D}} \mathrm{U}_{10}{ }^{2}
$$

$C_{D}$ : 抵抗係数 $\left(\doteqdot 1.0 \times 10^{-3}\right)$

の関係が成り立つと仮定した。その結果, $\mathrm{U}_{10}$ と $\mathrm{U}_{4}$ は次の関係になる。

$$
\mathrm{U}_{10}=\frac{\mathrm{U}_{4}}{1-\frac{\sqrt{\mathrm{C}_{\mathrm{D}}}}{\kappa} \log \frac{10}{4}}=\frac{\mathrm{U}_{4}}{0.97}
$$

$\mathrm{U}_{10}$ は上式に基づいて決定された。なお, 風速分布

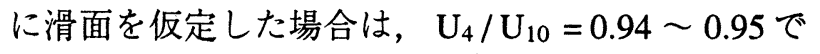
あった。

\section{4. 観測結果の考察}

（1）風について

図一 9 に風速と風向の関係を示す. 風速の最大 


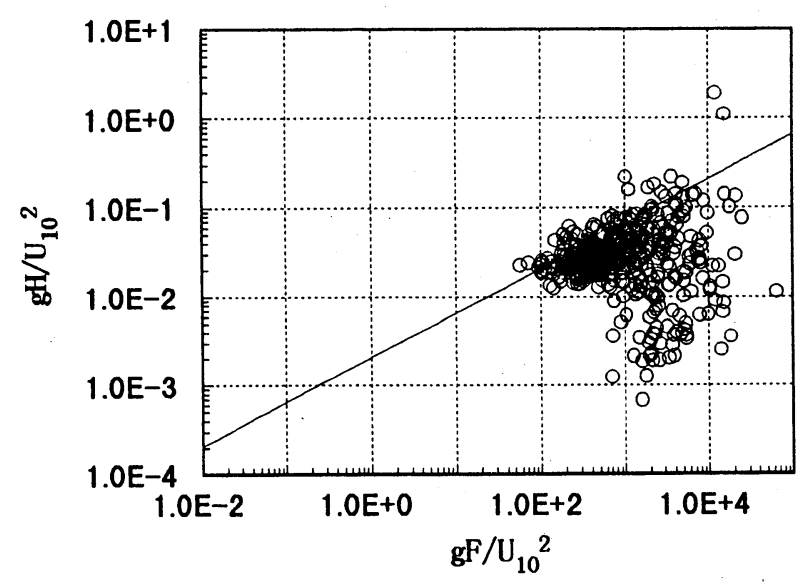

図-12 風速及び吹送距離の関係の無次元表示

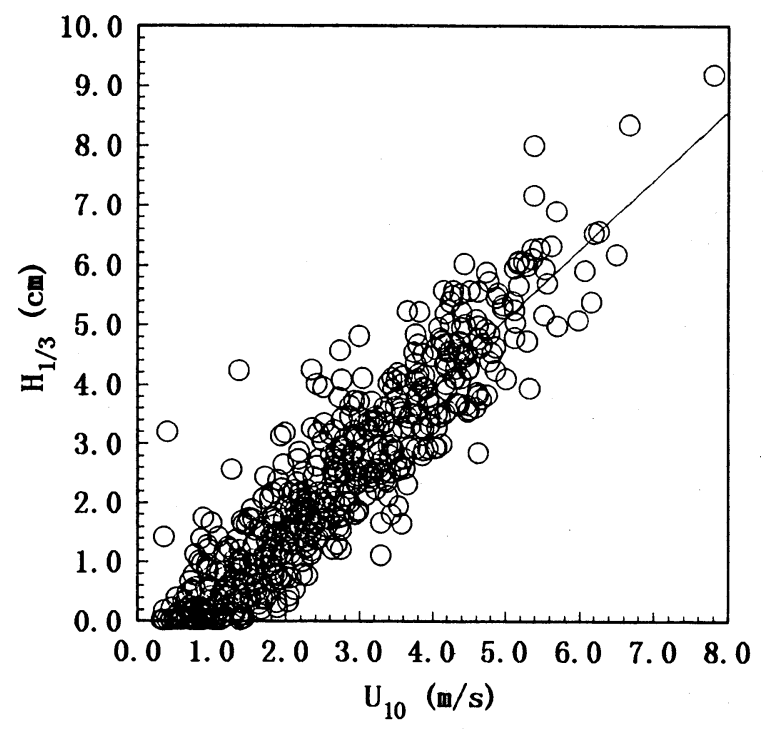

图ー14 $\mathrm{H}_{1 / 3}$ と $\mathrm{U}_{10}$ の関係に対する近似線

值は $8 \mathrm{~m} / \mathrm{s}$ であるが，通常は $5 \mathrm{~m} / \mathrm{s}$ 以下の風が吹い ていたことが分かる。.また，図一 3 と合わせて考 えると，両側を山で囲まれて長細い形状をした松原 ダム湖では，風は地形の影響を強く受けて水域の長 軸方向に発生頻度が高くかつ大きな風速の風が発生 することが分かる．図一 10 に風向の変化の一例を 示す. 風向は図一 9 で示したように $140^{\circ}$ （南南 東）及び $360^{\circ}\left(0^{\circ}\right)$ (北) からの風の発生頻度が確 かに高いが，同じ方向から 1 日以上吹き続けること はほとんどなく，松原ダム湖は一様風域場とは言い 難い水域と言える.

\section{（2）風と波の関係}

図一 11 は $\mathrm{H}_{1 / 3}$ と $\mathrm{U}_{10}$ の関係を吹送距離 $\mathrm{F}$ をパ ラメータとして示したものである。松原ダム湖で発 生する波の波高は概ね $6 \mathrm{~cm}$ 以下であることが分か る。吹送距離 $\mathrm{F}$ は風向を 16 方位に分割し図一 3 から決定した．図中の直線はWilsonの IV 型の波浪 推算式(から得られている. 直線とデータを比較する

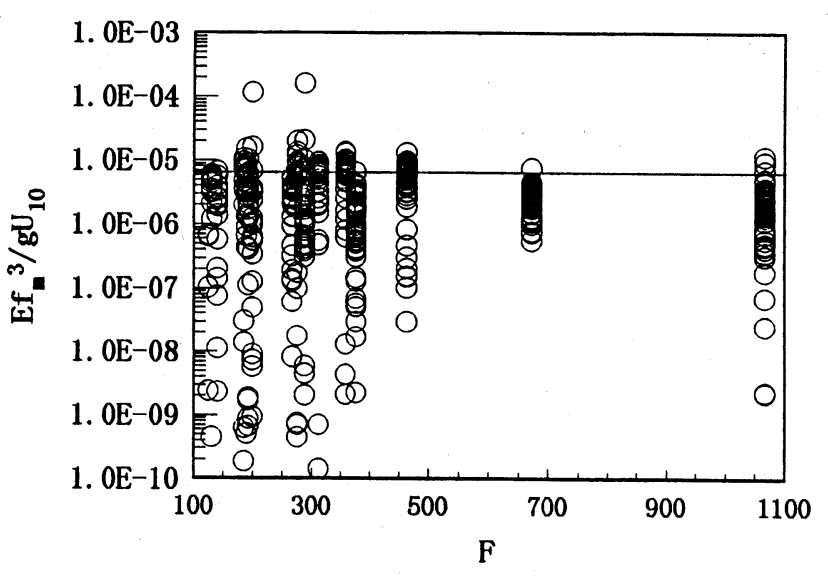

図ー13 $\quad \mathrm{Ef}_{\mathrm{m}}{ }^{3} / \mathrm{gU}_{10}$ と $\mathrm{F}$ の関係

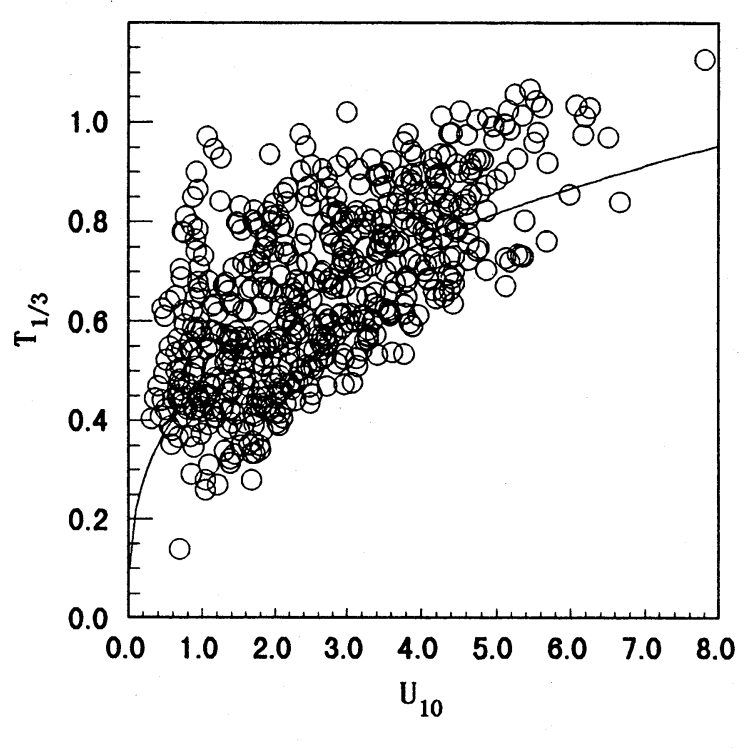

図ー15 $\mathrm{T}_{1 / 3}$ と $\mathrm{U}_{10}$ の関係

と，波高は吹送距離にそれ程強くは依存していない ことが分かる．図一12 に無次元表示された風速お よび吹送距離の関係を示す．図中の実線はWilsonの IV 型である。この図からも観測結果の多くは吹送距 離則に支配されていないということが分かる，図一 13 に $\mathrm{Ef}_{\mathrm{m}}{ }^{3} / \mathrm{gU}_{10}$ と $\mathrm{F}$ の関係を示す。ここで $\mathrm{E}$ はスペ クトルの全エネルギーであり， $\mathrm{f}_{\mathrm{m}}$ はスペクトルの ピーク周波数である. $\mathrm{E}$ は次式

$$
\mathrm{H}_{1 / 3}=4.00 \sqrt{\mathrm{E}}
$$

の関係から決定した。もし波が定常状態に達してい るならば

$$
\frac{\mathrm{Ef}_{\mathrm{m}}^{3}}{\mathrm{gU}_{10}}=6.84 \times 10^{-6}
$$

を満足しているはずである6). 観測で得られた $\mathrm{Ef}_{\mathrm{m}}{ }^{3} /$ $\mathrm{gU}_{10}$ はほとんど式 (5)を満足していないことから， 松原无么湖の波の多くは定常状態に達していない風 波であったことが分かる，そのために波高に吹送距 離への依存性が強く現れない結果になったものと思 
われる。

図一 14 の実線は，波高と風速の関係全てに対し て最小 2 乗法を施して得られたものである，その関 係を定式化すると次式となる。

$$
\mathrm{H}_{1 / 3}=2.10 \times 10^{-3}\left(\frac{300}{\mathrm{~g}}\right)^{\frac{1}{2}} \mathrm{U}_{10}-0.7 \quad(\mathrm{~cm})
$$

上式を変形すると次式が得られる.

$$
\frac{\mathrm{g}\left(\mathrm{H}_{1 / 3}+0.7\right)}{\mathrm{U}_{10}^{2}}=2.10 \times 10^{-3}\left(\frac{\mathrm{g} \cdot 300}{\mathrm{U}_{10}^{2}}\right)^{\frac{1}{2}}
$$

これは有義波の発達に関する吹送距離則

$$
\frac{\mathrm{gH}_{1 / 3}}{\mathrm{U}_{10}^{2}}=2.10 \times 10^{-3}\left(\frac{\mathrm{gF}}{\mathrm{U}_{10}^{2}}\right)^{\frac{1}{2}}
$$

において, $\mathrm{F}=300 \mathrm{~m}, \mathrm{H}_{1 / 3}$ を $\mathrm{H}_{1 / 3}+0.7$ とした場合 に相当する。このことは, 水域の空間スケールを代 表吹送距離とすれば，松原ダム湖のように風向に よって吹送距離が異なりしかも風向が時々刻々変化 するため定常状態に達していない風波に対しても， 吹送距離則の式を用いて波高を推算しても問題はな いということを意味している．ただし切片の 0.7 $(\mathrm{cm}) に$ 関しては, 風速計の測定限界の問題もあり, 現在のところはっきりしていない.

図一 15 に周期と風速の関係を示す。発生した波 の周期は $0.4 \sim 1.0 \mathrm{~s}$ の範囲であったことが分かる.

これは $\mathrm{L}=1.56 \mathrm{~T}^{2}$ を用いて波長に換算すると, 発生 した波長の範囲は $0.25 \mathrm{~m} \sim 1.56 \mathrm{~m}$ であったことに なる. 図中の曲線は, 次式の吹送距離則

$$
\frac{\mathrm{gT}_{1 / 3}}{2 \pi \mathrm{U}_{10}}=5.19 \times 10^{-2}\left(\frac{\mathrm{gF}}{\mathrm{U}_{10}^{2}}\right)^{\frac{1}{3}}
$$

に，波高に対して用いた代表吹送距離 $\mathrm{F}=300 \mathrm{~m}$ を 代入して得られた関係である。観測で得られたデー 夕が非常にばらついているため, 周期に関して代表 吹送距離を用いて得られた関係が妥当であるか否か は判断し難いところである。
5.まとめ

松原ダム湖において冬期 2 ケ月間の波浪観測を実 施した。明らかになった主要な点を以下に挙げる。

1）風は地形の影響を強く受け, 南南東及び北か らの風の発生頻度が多くかつ風速が大きい。

2) 発生する波の波高は概ね $6 \mathrm{~cm}$ 以下である.

3 ）発生した波の周期は $0.4 \sim 1.0 \mathrm{~s}$, また, 波 長の範囲は $25 \mathrm{~cm} \sim 1.56 \mathrm{~m}$ であった。

3 ）波の多くは定常状態に達していない風波であ る.

4) 水域の平均的な空間スケールを代表吹送距離 とすれば，吹送距離則の式を用いた波高の推 算が可能である.

謝辞: 本研究は文部省科学研究費 (特別研究員奖励 費）の補助を受けた。ここ記して，感謝の意を表し ます。

\section{参考文献}

1）小松利光, 岡田知也, 松永信博, 櫨田操, 藤田和夫： 波浪エネルギーを利用したダム湖・貯水池の水質改善 に関する基礎的研究, 水工学論文集, 第 41 巻, pp. 391-396, 1994.

2）小松利光, 岡田知也, 丸井茂俊, 松永陽一郎, 藤田和 夫, 柴田敏彦: 波浪エネルギーを利用したダム湖・眝 水池の水質改善法に関する現地観測, 水工学論文集, 第 42 巻, 1998.

3）高村浩彰, 多田彰秀, 安川武志, 市川衛: ダム貯水池 内での波浪観測について, 第 50 回年次講演会概要集, pp. $758-759,1992$.

4）岩垣雄一, 土屋義人, 酒井哲郎ほか：琵琶湖における 波浪観測について, 京大防災研年報, 第 19 号 B, pp. $361-379,1976$.

5）光易恒：博多湾の風と波一低風速時の一例一, 第 15 回 海岸工学講演会講演集, pp. 58-64, 1968.

6）光易恒：海洋波の物理, 岩波書店, 1995 .

(1997. 9. 30 受付) 